Historic, Archive Document

Do not assume content reflects current scientific knowledge, policies, or practices. 


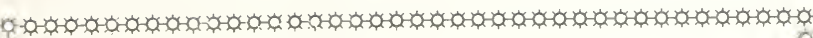

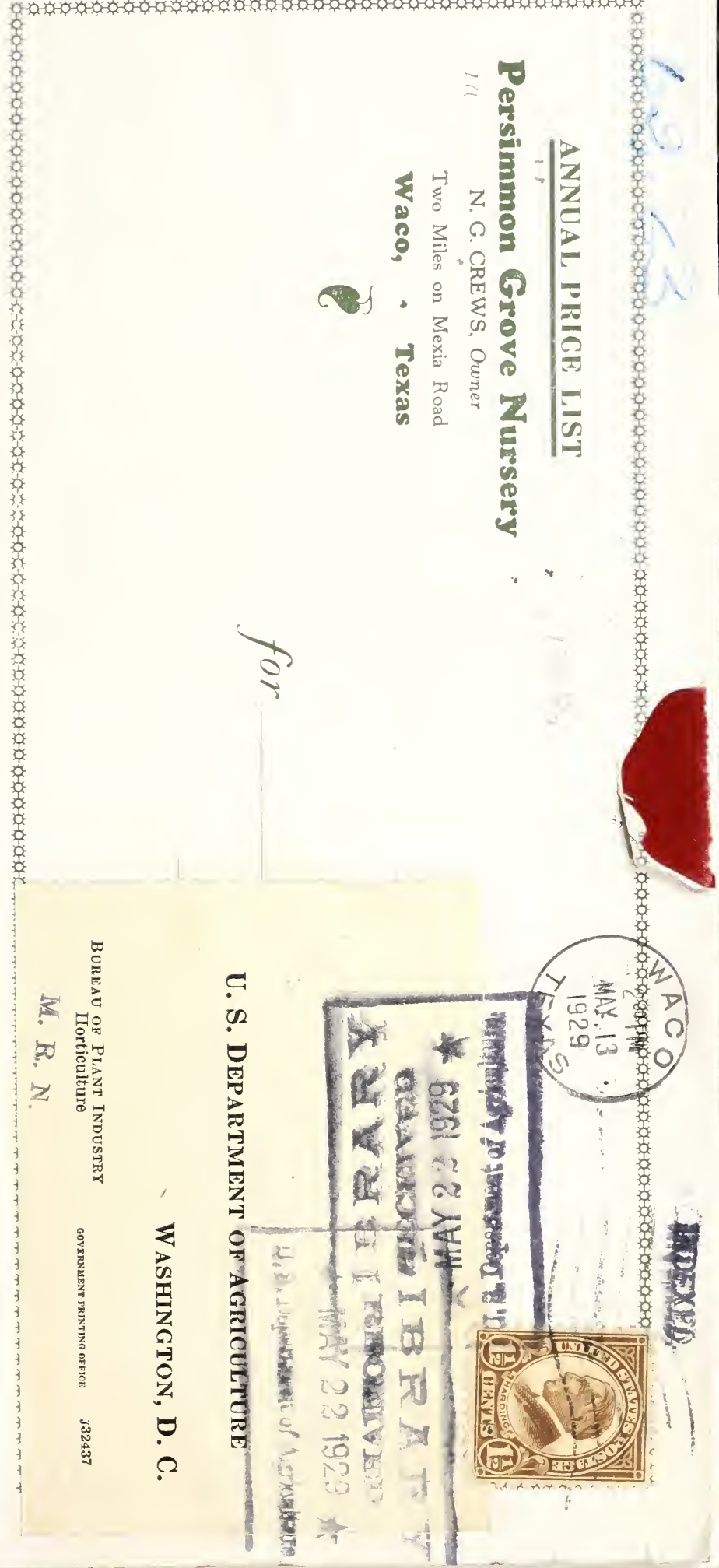




\section{TO THE TRADE}

Up to the last season, we catered almost exclusively to the trade of Fruit produeing and Fruit bearing trees and vines, but the demand became so greai for making the HOME MORE BEA TTTFUL by use of plants that we added a general line of Ormamental Shrubs and Evergreens, and we felt much gratified with the amount of business that came through the kindmess of our friends which we sincerely thank them for, and feel with many added varieties and larger specimens and plants than last season, we can serve you much better.

We do not have a yard in the city (and that extra overhead expense) as our nursery is just two miles out on a good highway, and we believe when you look over our price list you will readily see that for your short drive you will be able to save $25 \%$ to $35 \%$. Then you can get most if not all your order dug fresh from the nursery row.

I keenly appreciate your business and good will, which I value far more than monetary rewards and solicit your further patronage and íriendship.

\section{JAPAN PERSIMMON}

The Japan Persimmon is one of the most delicious fruits and is stcadily growing in favor. The trees are strong growers, very prolific, and exrly bearers, as they produce fruit on the new growth of each yez this gives them the advantage of one year in bearing over most

cnf other kind of fruit.

C an ornament, they are the most beautiful of any fruit producing trkes. The region in which the fruit may be grown covers a wide ranse of the cotton states.

Commercial orchards are already being established in several sections of the country.

There is an impression by some that all fruits of the Persimmon are not pslatab!e until they are on the verge of decay or until after frost. This impression is erroneous, as fruits of the sweet varieties, of which we hrve three, are exccllent and meaty, even while yet hard, and we usually have some ripe fruit from September 15 to Christmas.

To give you some idea of the popularity of the Japanese Persimmon durizg the ripeaing season, which is from September 15th to Decembar 30th, from my register more than two thousand people have visited Persinmon Grove from Wceo and Texas, and more than onehalf the States and some foreign countries and have seen it in fruit. A large $p^{-1}$ cert of these pacp'e are customers, and you too, no doubt would be if you should see them in all the richness of their glory (fruitins). A very beautiful sight indeed.

\section{HOW TO TRANSPLANT JAPANESE PERSIMMONS}

As most Japanese Persimmon trees hare tap roots with few laterals, my method of transplanting is to use a post hole digger and make the excavation just large enough to admit the lateral roots and four to six inches deeper than the roots are long. This done, turn the roots of your tree up and give the tips of each root a fresh cut, then place 
the roots in the hole with the bow, if any, to the south, and lan the tol' a little to the southw.st, then with shovel take the best loamy top earth you can find and fill the hole twothirds full and put in a bucket of water; then take hold of the tree and pull it up to a point where the ground mark on your tree is from one to two inches below the ground level. Then work tree ul, and down and sideways until you are sure that the water has settled the dirt to the point of the roots, then finish filling the hole with good top earth. Do not use any fertilizer, but keep a malch worked up four or five feet around your trees all the time with a hoe, if they are not where they can be cultivated with a llow.

In setting an orchard, distances of 15 to $18 \mathrm{fe} t \mathrm{t}$ each way is recommended. The roots of the trees should not be allowed to dry out. The top should be pruned to 18 inches to 2 feet on an average sized tree.

If there is any further information I can furnish you, I shall be glad to do so, and shall appreciate your order, large or small, and will endeavor to handle it in a satisfactory manner.

All the following varieties that I am offering for sale I have fruited here and anyone can see for themselves just what they are. All grafting wood is taken from these trees by myself, and I know what they are; as one saying goes, "I grew up with them.",

HACHIVA - One of the largest and most beautiful of the Japan varietics, oblong, conic, ripening through October.

Flesh yellow, skin dark bright red with oceasional dark blotches and rings at the top. Trees upright, vigorous and shapely.

FUYU-This new variety was originated in Japan only a few years ago, and $I$ got it direct from parties introducing it in this country. It is recommended highly by the Agriculture Department of Japan for commercial planting, as it is said never to be astringent, and may be eaten while still hard like an apple; dessert quality one of the best.

YEDOICHI-Large, roundish oblate in shape; skin darker red than most sorts; flesh dark brown and crisp, non-astringent when still hard, quality one of the best. Tree upright, thrifty grower.

TRIUMPH-Medium sized, tomato shaped and colored, seeds vary from none to 5 or 6 . Astringent till soft except where they have seed; matures through a long period. The best dessert quality; bears in clusters. 
HYAKUMA - One of the largest, tomato shaped, but orange colored. Flesh brown in color when several seeds develop, sweet and meaty: may be eaten while still hard except light colored seedless portions. Trees large open top.

TAMOPAN-This is the only variety of the Japanese group of persimmons established in this country that had its origin in Chira, having been found west of Pekin.

It is very large, oblate, usually tending to be 4 -sided and with a peculiar constriction extending entirely around the fruit somewhat above the middle. Flesh light colored, astringent until fully ripe, àlmost seedless. Ripens rather late, the bulk of the fruit being in season in Norember.

TSURA-Medium to large, slender conical, light colored flesh, astringent till fully ripe, and one of the latest to ripen but very fine and prolific bearer.

This variety is different in many ways to any I know, having a slender leaf with that rich, lustrous green and smooth bark and fruit hanging in clusters would make an ornament for any lawn.

JAPANESE PERSIMMON PRICES Each 10

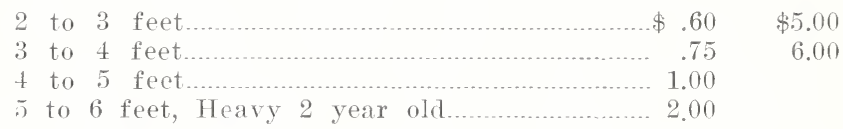

NATIVE PERSIMMON (SEEDLING) PRICES:

$\begin{array}{lllrrr}3 \text { to } 4 \text { f'tet } & \text { Each } & \text { Per } 10 & \text { Per } 100 \\ 4 \text { to } 5 \text { feet } & .35 & \$ 3.00 & \$ 25.00 \\ 12 \text { to } 18 \text { inch } & .50 & 4.00 & \\ 12 & .10 & .75 & 5.00\end{array}$

\section{PAPER SHELL PECANS}

All grafted on native stock and the best root system grown. I found sevcral trees in nursery row, second year from graft, with 12 or 15 large nuts to the tree.

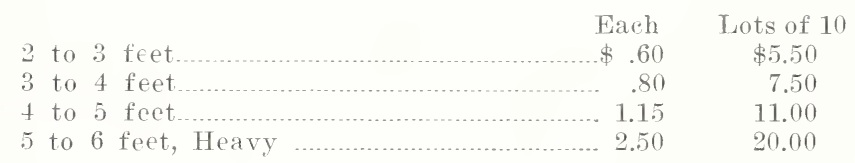

\section{WESTERN VARIETJES}

Burkett Stuart Delmas

IIalbert Texas Prolific Schley

\section{PEACHES}

In the last 15 years I have fruited 25 varieties of Peaches and out of that number I have a selection that I would recommend for planting in this section. They are as follows, in order of ripening:

Mayflower (semi-free) 10 to 20 May;

Alexander (semi-free) 20 to 30 May;

Dwarf Blood (semi-free) 1 to 10 June;

Mamie Ross (free) 10 to 20 June; 
Hobson Cling, 20 to 30 June;

Elberta (free) 1 to 20 July;

Elberta (Jing.

Judian Cling, 1 to 15 August.

This is the original old time Indian Peach that we knew 25 years ago and is so near extinct.

I traveled 200 miles a few years ago for wood from a tree-which is now dead-to graft, and get my start, it being the best Indian Peach I had seen for 25 years. I have out something like 100 of these trees and this year when I had the fruit on the market, they were pronounced the old original Indian Peach by all the old-timers who saw them. I have a few of these trees that I am offering the trade; 2 year old stock that will rum from 3 to 5 feet, at $\$ 1.00$ each or $\$ 7.50$ for 10 .

\section{OTHER TARIETIES}

\begin{tabular}{|c|c|c|c|}
\hline 18 inches to 2 feet & $\begin{array}{l}\text { Each } \\
\$ .20\end{array}$ & $\begin{array}{l}\text { Doz. } \\
\$ 2.00\end{array}$ & $\begin{array}{r}100 \\
\$ 15.00\end{array}$ \\
\hline 2 feet to 3 feet.... & .25 & 2.50 & 20.00 \\
\hline 3 feet to 4 feet.......... & 35 & 3.50 & 30.00 \\
\hline 4 feet to 5 feet, Heary... & .50 & 5.00 & \\
\hline xtra Heary .................. & 1.00 & 10.00 & \\
\hline
\end{tabular}

\section{PLUMS}

Of Plums I have fruited 27 rarieties and from those I have selected a few varieties for this section and are all good. They are as follows in order of ripening:

Six Weeks, May 10 to 25.

America, June 1 to 15.

Texas Prolific, July 1 to 15.

$\checkmark$ Barbara, July 15 to 30 .

Bartlett, July 10 to 20.

It is common with plums to be prolific, in fact too much so, and 0 bear early, thereby weakening the tree, and the result is most rarieties are short-lived, but not so with these, except Texas Prolific; the other four varieties do not bear much until the third year, and all are common to this seetion except Barbara, which is really a wonder, not so much from productiveness, but from size, color and flavor. They are the size of a small apple, and have such a rich red color, that they look almost transparent, and while they have plenty of juice, they are not watery like many plums, but are meaty and have a very small seed.

How strange! so many people don't know what they can grow in Texas-and this place we call HOME.

So much in demand were these plums that they brought at the rate of $\$ 6.00$ per bushel readily.

I have a few of these trees 2 to + feet.

Each Doz. $\$ .75 \$ 7.50$

\section{OTHER VARIETJES}

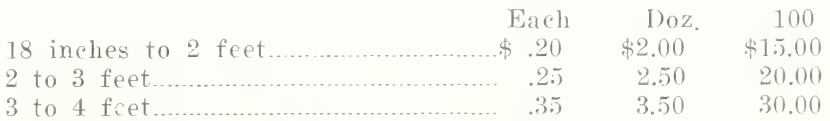




\section{APRICOTS}

I have fruited three varieties, but find that the Early Golden is the most satisfactory for this section. Ripens in June.

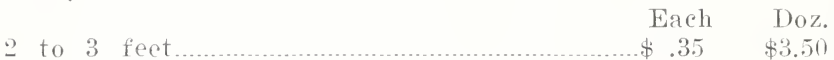

3 to 4 feet, Heary

\section{FIGS}

Have fruited several varieties here, but find the Celestial or Green Ischi the most hardy and productive of all.

$\begin{array}{rrrrr}2 & \text { to } 3 \text { feet } & \text { Each } & \text { Doz. } \\ 3 & \text { to } 4 \text { feet, Heary } & \end{array}$

\section{FRUITING POMEGRANATE}

The Pomegranate is quite hardy on most any soil, and is very ormamental as well as producing fine fruit of fresh crispmess, delicacy and sprightliness of flavor, much esteemed by many. Large oval shape with erimson blush next to the sun. Should be planted more.

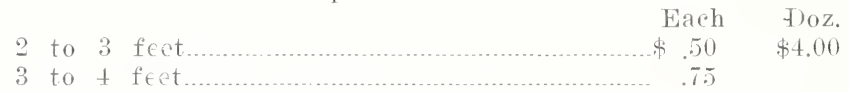

\section{GRAPES}

One of the best, healthiest and longest eultivated fruits we have. Easy to grow in most any kind of soil that is not too wet. Where there is little room, plant them along the fence or on the side of a building. In pruning, never forget that grape vines grow fruit only on last year's shoots.

We have fruited sereral varieties, but find the four kinds listed below the most satisfactory of any.

CACO GRAPE-In aplearance the most beautiful of hardy grapes; berry large, wine red. Bunch of good size compact, and of good form; rijens 10 days in advance of Concord.

CONCORD-Black, the well known, fine old rariety planted everywhere. Bunches and berries of good size. Skin tender, juicy and sweet when fully ripe. Very hardy and productive.

CARMAN-Black. The berries almost as large as the Concord, but the bunches are more compact and is the best adapted grape for this section that we have fruited, and is said to be the best wine grape.

GOETHE-White. The largest berries and most thrifty growing vine of any that we have fruitcd, and we believe is destined to become the best commercial grape for this section. Ripens July 20 to August 1.

PRICES:

\begin{tabular}{|c|c|c|}
\hline & Each & Doz. \\
\hline year old & ... $\quad .25$ & 1.75 \\
\hline
\end{tabular}


When small the tree is of conical regularly shaped outline with wide spreading branches, but as the tree incrases in age it assumes a round open head, a change from the beantiful to the pieturesque. Aside from its ormamental value, it is of peculiar interest for its seriptural and historical association. It is said to be the most hardy of the cedrus family.

BALLET ANT) BURLAPPED (B \& B)

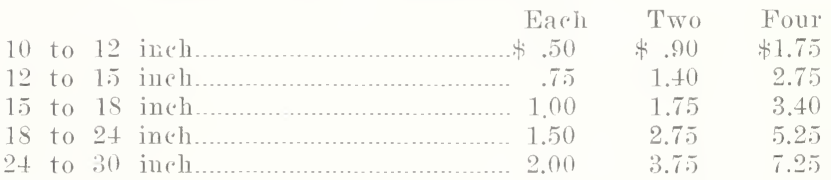

\section{CUPRESSUS SEMPERVIRENS (Italian Cypress)}

This is a tall, slemder evergreen, straight and colmmuar. Its dark green shaft rising abore other shrubbery, gives a varied sky line. It is equally at home in small grounds or large ones, with the cottage or the larger house. During a long life, it reaches great height. This is the tree which so many American tourists in Ttaly become enthusiastic about.

$$
(B \& B)
$$

\begin{tabular}{|c|c|c|c|}
\hline & Each & Two & Four \\
\hline is to 24 inc & $\$ .75$ & $\$ 1.40$ & \\
\hline to 3 feet & .1 .00 & 1.90 & \\
\hline to \pm feet & .1 .50 & 2.75 & 5.40 \\
\hline to 6 feet & 3.00 & 5.75 & 11.00 \\
\hline
\end{tabular}

\section{CUPRESSUS HORIZONTALIS (Horizontal Cypress)}

Same price as Ttaliau Cypress- (B \& B).

\section{CUPRESSUS ARIZONICA (Arizona Cypress)}

Attractive for its silvery blue color. Beautiful blue pyra midal tree, horizontal branching, dense foliage. Attains 20 feet, making perfectly shaper specimen.

\begin{tabular}{|c|c|c|c|}
\hline$(B \& B)$ & Eacl $_{\iota}$ & Two & Four \\
\hline 18 to 24 inch. & $\$ 1.00$ & $\$ 1.90$ & $\$ 3.75$ \\
\hline to 3 feet.... & 1.50 & 2.80 & 5.50 \\
\hline to 4 feet. & 2.50 & 4.80 & 9.00 \\
\hline
\end{tabular}

\section{THUJA OCCIDENTALIS (American Arbor-Vitae)}

The American Arbor-vitae is the mother tree from which upward of tifty distinct trpes lave beeu developed. The Arbor-vitae is very hardy and dependable in almost any situation. Stands trimming well and for this reason is widely used for hedge purposes. It usually grows bushy at the bottom and tapering toward the top. Foliage is very soft and flexible and of fine deep green color.

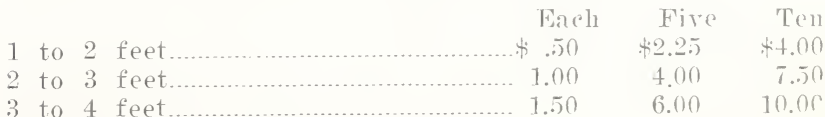




\section{CALIFORNIA PRIVET}

\begin{tabular}{|c|c|c|c|}
\hline & 10 & 25 & 50 \\
\hline to 18 inch & $\$ 1.00$ & $\$ 2.00$ & $\$ 3.50$ \\
\hline to 3 feet, well bra & 1.75 & 3.50 & 6.50 \\
\hline
\end{tabular}

\section{AMOOR PRIVET}

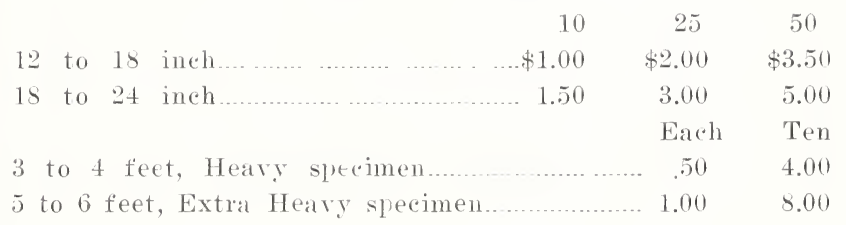

\section{FLOWERING SHRUBS}

CREPE MYRTLE-Two years old. Colors: Pink, Purple, Red, and White.

18 to 24 inch.

$250 \quad 2$ to 3 feet.

40

ALTHEAS-Double Red, Double Pure White, and SemiDouble Pink.

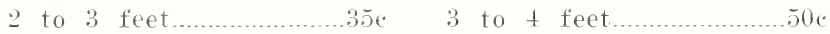

\section{CANNAS}

Each Doz.

Burbank, Florence Vaughan, Queen Hel, ne and Madam Crozy.

Bulbs

$.15 \quad \$ 1.25$

CYDONIA (Flowering Quince)-This is one of the first shrubs to bloom; it is rery noticeable and is sometimes planted as a flowering hedge.

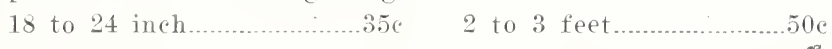

PINK DEUTZIA (Pride of Rochester)-Flowers double white, back of the petals tinged with rose. One of the best; blooms in July; very floriferous.

18 to 24 inch.......................25c 2 to 3 feet $40 \mathrm{c}$

PARKINSONIA - A large, showy ormamental shrub with bright green bark. Foliage consists of feathery, reed-like branchlets which hang in bunches. A handsome shrub at all times, and doubly so in spring and most of summer, when it bears an abundance of handsome yellow flowers.
4 to 6 feet $\$ 1.50$ each
6 to 8 feet $\$ 2.00$ each

\section{ROSES}

Many varieties of field grown (budded and grafted) Roses in all colors. 


\section{EUONYMUS JAPONICA (Evergreen B.)}

Leaves dark, shining green. A fine plant for the lawn. Succeeds in almost any situation.

Two-year, well branched.

(Balled)

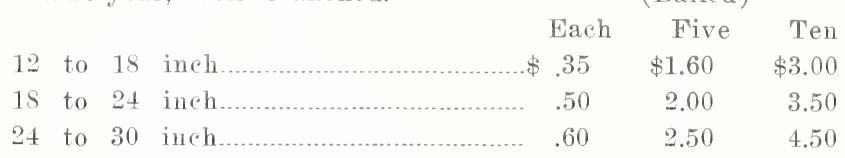

\section{LIGUSTRUM}

\section{LIGUSTRUM PYRAMIDALIS (Upright Wax-Leaf Privet)}

Leaves are rather pointed and not quite as thick as Lucidum, and the growth is decidedly upright. For corner of house, between windows and as background planting, this is indispensable.

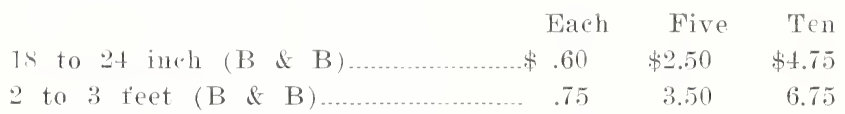

\section{LIGUSTRUM JAPONICUM (Japanese Privet)}

A very handsome broad-leaved variety with large, darkgreen leavs. Flowers produced in panicles followed by purple berries, which are retained during the winter, giving the plant a very pleasing appearance. This plant can be grown into a small tre; can also be trimmed into pyramidal, standard or other forms. Ultimate height, 10 to 20 feet.

\begin{tabular}{|c|c|c|}
\hline & Each & Five \\
\hline to 24 inch. & .25 & $\$ 1.00$ \\
\hline to 3 feet (Balle & .40 & 1.50 \\
\hline to 4 feet, $\mathrm{He}$ & .75 & 3.25 \\
\hline to 6 fect, Extra Heavy (Ballec & 1.75 & 8.50 \\
\hline
\end{tabular}

\section{LUGISTRUM LUCIDUM COMPACTUM (Wax-Leaf Privet)}

Under this name many plants are offered, including seedlings which do not come true, but what we are offering are dwarf growing shrubs with very thick weavy leaves of extremely glossy surface. One of the most satisfactory plants for general planting, being free from attack of insects and diseases and fast grower, doing well in most adverse conditions.

$$
(\mathrm{B} \& \mathrm{~B})
$$

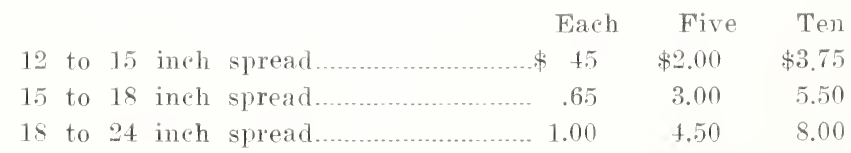




\section{SHADE TREES}

We have the Pecan, which you will find quoted elsewhere herein.

\section{SILVER LEAF MAPLE}

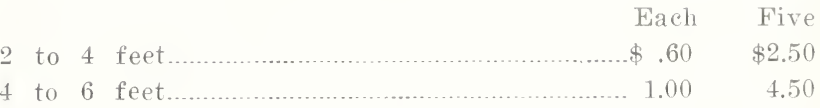

\section{COTTON WOOD}

Each Five

5) to 6 feet

.40

$\$ 1.75$

7 to 9 fcet

\section{SYCAMORE}

5 to 6 fieet $\$ 1.00$ Each

\section{CHINESE ELIM}

Each Five

2 to 3 ficet

40

$\$ 1.75$

4 to 5 fe t

.7 .5

3.50

\section{QUEREUS-LIVE OAK}

Evergreen tree. Horizontal branches, forming a wide spreading top. One of the most beautiful of the American oaks, owing to its beautiful form and its dark gre. $n$ foliage. Easily transplanted. When nursery grown trees are used, they make rapid growth. Long lived.

Each Five

1.) to $1 \mathrm{~s}$ inch $\$ .65 \$ \$ .00$

18 to 30 inch 1.00

4.00

\section{TALLOW TREE}

A new introduction from the Orient. Hardy, rapid growing tree. Soft, large heart-shaped leaves, making dense shade, and when better known I beliere will be a very popular shade tree. Fasy to transplant.

\begin{tabular}{|c|c|}
\hline 2 to 3 & $\begin{array}{c}\text { Each } \\
\ldots .65\end{array}$ \\
\hline to 4 feet. & 1.00 \\
\hline
\end{tabular}

A certificate of inspection is furnished with each order, and where orders are given for out of town customers we lack and ship direct, FREE OF CHARGE, where order's amount to as much as $\$ 3.00$.

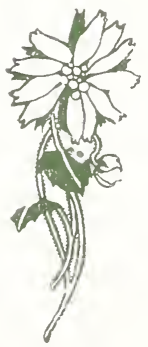




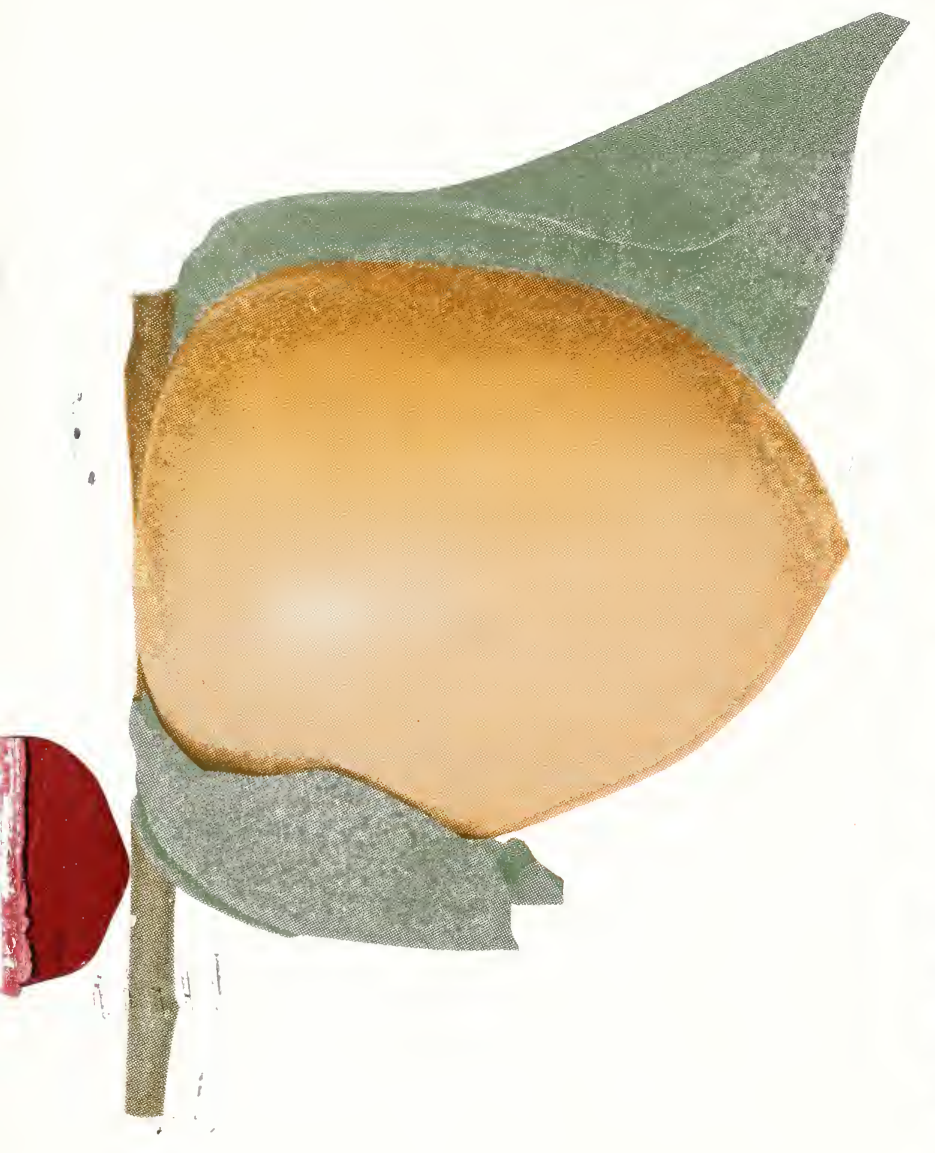

